Ann. Sci. forest., 1980, 37 (4), 357-359.

\title{
Is there a relationship between Dichaena rugosa and beech bark disease?
}

\author{
Eberhard O. SPEER and Heinz BUTIN \\ Laboratoire de Morphologie Expérimentale, \\ Institut de Botanique de I'ULP. Strasbourg \\ 28, rue Gœthe 67083 Strasbourg Cedex \\ Institut für Pflanzenschutz im Forst, \\ Biologische Bundesansialt für Lond- und Forstwirtschaft. \\ Hann. Münden (Germany)
}

\section{Summary}

The bark fungus Dichaena rugosa develops its fruit-bodies on beech and oak. There are ascospores, spermatia, macroconidia and chlamydoconidia. The hyphae of the fungus penetrate into the living cells of the bark, provoking the proliferation of periderm cells. Conidia are distributed by slugs and germinate after having passed through their alimentary canals. Cryptococcus fagisuga is able to attack fungus-infected periderm ; only secondary periderm is able to withstand the insect's attack.

Since it cannot be excluded that the interaction of several different organisms may be responsible for the so-called beech bark disease, we feel justified in discussing a fungus commonly found on beech bark. The fungus in question is Dichaena rugosa Fries (1849), also known as Ascodichaena rugosa Butin (1977). According to today's scientific knowledge, it belongs to the Phacidiales under the Ascomycetes. The fungus, considered a lichen (Opegrapha) by Persoon (1794), is easy to recognise by the black marks of varying size that it causes on twigs and trunks of beech and oak. When seen under the magnifying glass, these black areas are made up of densely growing, dark, hysterioid fruit-bodies and often the remains of the last season's stromata.

Microscopic observations show that the fruit-bodies can contain four different states :

\section{1. - Spermatia}

Their spermogonia develope stromatically. In the innermost schizogenous cavity grow simple or divided hyphae, bearing globose to ovoid spermatia, which accumulate under certain conditions on top of the spermagonia. 


\section{2. - Ascospores}

The ascomata break out of the periderm and appear round to elongate, opening by a simple, divided or stellate fissure. They contain, between numerous paraphyses, elongated asci with four to eight unicellular, hyaline to brownish spores. They are more common on oak than on beech.

\section{3. - Macroconidia}

The macroconidial state was described as Psilospora faginea by Rabenhorst (1856) and is characterised by its big hyaline, thin-walled conidia that form on simple conidiophores in the cavities of pyenidia that do not - superficially seen - differ from the fruit-bodies of the other states. They can be found throughout the year, even in mild winters.

\section{4. - Chlamydoconidia}

This form of fructification was described by Paoli (1905) as Dichaenopsis Notarisii. The chlamydoconidia develope on short conidiophores in pyenidia, which are like those of the macroconidia. They are, however, brownish, thick-walled, septate and usually smaller than the macroconidia. They are generally somewhat irregular in shape.

Although Wallroth (1825) had already supposed the fungus in question to be a parasite, nobody in the last 150 years has ever bothered to find out more about its growth ; doubtless because the fungus was commonly considered a harmless epiphyte which lived off the dead parts of the bark.

Our own observations in this direction have shown the following :

The fungus attacks the youngest twigs as well as the oldest parts of the trunk of Fagus sylvatica. The hyphae penetrate into the periderm and grow intracellularly in the phellem. The infection hyphae penetrate haustoria-like into the cells. There they continue growing, finally densely filling the cell lumen. Usually, they do not penetrate further than the phellogen ; but it happens now and then that the hyphae grow deep into the phelloderm. As parasitism on plants in general is accompanied by cytological and morphological reastions of the host tissue (Speer, 1971), so is parasitism on bark. In our case, the infected periderm thickens often up to four times that of the healthy periderm. This process happens because on the one hand the phellogen produces more cork cells, and on the other hand because the volume of the infected cells is larger than that of the healthy ones. There where the fungus penetrates the phelloderm, the infected and the near-by cells become suberised. The cell walls are not destroyed by the fungus ; it penetrates these via their pores.

Thus we believe that Ascodichaena is a true parasite which does not actually cause any damage worth mentioning. However, it cannot be excluded that under certain conditions a premature die-back of the lowest branches or of young trees can be influenced by a heavy attack of the fungus.

The ecological aspects of this fungus are no less interesting. For example, we did not succeed in making the macroconidia germinate in the laboratory. But the observation that in damp weather various slugs and snails were eating up the fungus, gave us a clue. We collected their excrement and found out that it still contained undigested conidia, which were either germinating or did so after a few days in 
water. We could conclude that the macroconidia need the influence of the digestive juice of the animals to germinate. Distribution of fungi through animals, particularly insects, is nothing new (Speer, 1974). In our case, the distribution through molluscs may be new.

Another important point of view seemed to us to be the relationship between the fungus and the beech scale (Cryptococcus fagisuga). The question was whether the fungus attracted or deterred the insect. We saw that the fungus infection and the resulting thickening of the periderm did not hinder it. Even on trunks not densely infected by the fungus, we found the insect both on healthy and on infected areas. It was seen on slides that its mandibles could easily penetrate through the thickened phellem into the bark parenchyma. It is obvious that the gaps between the fruit-bodies give the insects an even better protection than does the relatively smooth, uninfected bark. It can be agreed that Ascodichaena promoted the distribution of the beech scale, rather than protecting the trunk against it. That the wax secretion of the insect is stuck between the various rough stromata of the fungus and cannot expand as on smooth, healthy bark, gives the impression that the fungus-infected areas are free from Cryptococcus. But under certain circumstances the fungus can indeed limit attacks of this insect. This occurs on beeches that react to the fungus infection by forming here and there a secondary periderm. On such areas we never found an attack of beech scale.

\section{Reçu pour publication en décembre 1979.}

\section{Résumé}

Le champignon Dichaena rugoso forme ses fructifications sur l'écorce des hêtres et des chênes. Elles contiennent des ascospores, des spermaties, des macroconidies et des chlamydoconidies. Les hyphes du champignon qui pénètrent jusqu'aux cellules vivantes du périderme provoquent leur multiplication. Les conidies peuvent être disséminées par des limaces ef elles germent après avoir transité par leur tube digestif. Une cochenille, Cryptococcus fagisuga, est capable d'attaquer le périderme infecté par le champignon. Toutefois l'épaisseur du périderme secondaire résultant de la présence de $D$. rugosa est défavorable à la cochenille.

\section{Zusammenfassung}

Der Rindenpilz Dichoena rugosa entwickelt seine Fruchtkörper auf der Rinde von Buche und Eiche. Es werden Askosporen, Spermatien, Makrokonidien und Dauerkonidien gebildet. Die Hyphen des Pilzes dringen bis in die lebenden Rindenzellen vor und provozieren vermehrte Bildung von Peridermzellen. Konidien des Pilzes werden durch Schnecken verbreitet; sie sind keimfähig, nachdem sie den Darmirakt derselben passiert haben. Die Buchenwollaus ist in der Lage, verdicktes primäres Periderm zu durchstechen. Dort, wo auch sekundäres Periderm gebildet wird, konnte kein Befall durch die Buchenwollaus festgestellt werden.

\section{Références bibliographiques}

BUTIN H., 1977. Taxonomy and morphology of Ascodichaena rugosa gen. ef sp. nov. Trans. Brit. Mycol. Soc., 69 (2), 249-254.

FRIES E., 1849. Summa Vegetabilium Scancinoviae 2, 402.

PAOLI G., 1905. Note critiche su alcuni Isteriacei Nuovo Giorn. Bot. Ifol. n. s. 12 (1), 91-115. Gennaio.

PERSOON C. H., 1794. Einige Bermerkungen über die Flechten : Nebst Beschreibung einiger neuen Arten aus dieser Familie der Aftermoose. Ann. Bot. (Usteri), 7, 1-160, Tab. I-III.

RABENHORST L., 1856. Psilospora Rabenh. nov. genus. Hedwigia 1 (16), 107-108, 1 pl.

SPEER E. O., 1971. Untersuchungen an einigen parasitischen Pilzen und ihren Wirtspflanzen. Sydowia XXV (1-6), 1-34, Taf. I-XI.

SPEER E. O., 1974. Un nouveau cas de zoochorie chez les champignons : Dispersion de périthèces de Phyllactinia ssp. (Erysiphacées) par des insectes. Bull. Soc. Mycol. France, 90 (2), 97-99.

WALLROTH F. W., 1825. Naturgeschichte der Flechten. I. 